University of Massachusetts Amherst ScholarWorks@UMass Amherst

2008

\title{
Determination of lead by hydride generation atom trapping flame atomic absorption spectrometry
}

NErtas

Z Arslan

JF Tyson

Follow this and additional works at: https://scholarworks.umass.edu/chem_faculty_pubs

Part of the Chemistry Commons

\section{Recommended Citation}

Ertas, N; Arslan, Z; and Tyson, JF, "Determination of lead by hydride generation atom trapping flame atomic absorption spectrometry" (2008). JOURNAL OF ANALYTICAL ATOMIC SPECTROMETRY. 1002.

Retrieved from https://scholarworks.umass.edu/chem_faculty_pubs/1002 


\title{
Determination of lead by hydride generation atom trapping flame atomic absorption spectrometry
}

\author{
Nusret Ertaș, ${ }^{a}$ Zikri Arslan*b and Julian F. Tyson ${ }^{c}$ \\ Received 7th August 2007, Accepted 2nd October 2007 \\ First published as an Advance Article on the web 11th October 2007 \\ DOI: $10.1039 / \mathbf{b} 712126 \mathrm{a}$
}

An atom trapping approach is described for the determination of lead by hydride generation flame atomic absorption spectrometry. Lead hydride $\left(\mathrm{PbH}_{4}\right)$, generated on-line by reacting lead in hydrochloric acid-potassium ferricyanide medium with sodium borohydride $\left(\mathrm{NaBH}_{4}\right)$, was trapped on the interior walls of a slotted T-tube under highly oxidizing flame conditions. Atomization was achieved by aspirating $50 \mu \mathrm{L}$ of methyl isobutyl ketone (MIBK) to the flame. Optimization of the experimental parameters for the generation and collection of lead hydride was described to achieve the highest peak height sensitivity. The detection limits were $0.075,0.047$ and $0.028 \mu \mathrm{g} \mathrm{L}^{-1}$ for $2.6,5.2$ and $7.8 \mathrm{~mL}$ of blank solution $(n=13)$, respectively. Calibration was linear up to $3.0 \mu \mathrm{g} \mathrm{L}^{-1}$ for a 30 -s trapping period. The relative standard deviation was between 2 and 4\%. The method was successfully applied to the determination of $\mathrm{Pb}$ in NIST certified reference materials, San Joaquin Soil (SRM 2709) and Apple Leaves (SRM 1515).

\section{Introduction}

Flame atomic absorption spectrometry (FAAS) is a robust, low cost and simple technique. However, the detection limits of conventional FAAS are not sufficiently low to accurately determine most heavy metals, such as lead $(\mathrm{Pb})$, at trace and ultra-trace levels, because of the limited atom number density in the light path associated with poor nebulization and atomization. Thus, FAAS is usually interfaced to on-line preconcentration and hydride generation procedures to improve the detection limits for the determination of $\mathrm{Pb}$ in environmental and clinical samples. ${ }^{1-3}$ On-line preconcentration via retention of $\mathrm{Pb}$ within a certain $\mathrm{pH}$ on a micro-column of a solid support improves the sensitivity and selectivity. ${ }^{4,5}$ Various procedures have been described for the determination of $\mathrm{Pb}$ by FAAS. $^{6-15}$ Most frequently, $\mathrm{C}_{18}$ bonded silica gel sorbent $^{11-15}$ is used as the support material, while other adsorbents, including activated carbon, ${ }^{16}$ alumina, ${ }^{17}$ cellulose, ${ }^{18}$ and Chromosorb 102, ${ }^{19}$ have also been used.

Hydride generation $(\mathrm{HG})$ has been a powerful means of sample introduction for the determination of hydride-forming elements, such as arsenic (As), antimony ( $\mathrm{Sb}$ ), bismuth (Bi) and selenium (Se), by FAAS due to the efficient transport and atomization of gaseous hydride..$^{20,21}$ Despite these advantages, the determination of $\mathrm{Pb}$ by hydride generation has been hindered by low chemical yield of lead hydride (plumbane, $\mathrm{PbH}_{4}$ ) for which $\mathrm{Pb}^{2+}$ needs to be oxidized to the $\mathrm{Pb}^{4+}$ oxidation state. In acidic solutions, the chemical yield of $\mathrm{Pb}^{4+}$ and hence that of $\mathrm{PbH}_{4}$ is limited by the relatively low

\footnotetext{
${ }^{a}$ Gazi University, Faculty of Pharmacy, Department of Analytical

Chemistry, Ankara 06339, Turkey

${ }^{b}$ Jackson State University, Department of Chemistry, PO Box 17910 Jackson, MS 39217,USA.E-mail: zikri.arslan@jsums.edu; Fax. +1 (601) 979-3674; Tel: + 1 (601) 979-2072

${ }^{c}$ Department of Chemistry, University of Massachusetts, Box 34510 , Amherst, MA 01003, USA
}

redox potential of $\mathrm{Pb}^{2+} / \mathrm{Pb}^{4+}(-1.455 \mathrm{~V}) .^{20-22} \mathrm{~A}$ number of oxidant-acid mixtures, including $\left(\mathrm{NH}_{4}\right)_{2} \mathrm{~S}_{2} \mathrm{O}_{8}-\mathrm{HNO}_{3}$ and $\mathrm{H}_{2} \mathrm{O}_{2}-\mathrm{HNO}_{3},{ }^{23-25} \mathrm{~K}_{2} \mathrm{Cr}_{2} \mathrm{O}_{7}$-lactic acid, ${ }^{26} \mathrm{H}_{2} \mathrm{O}_{2}-\mathrm{HCl}^{27}$ and $\mathrm{K}_{3} \mathrm{Fe}(\mathrm{CN})_{6}-\mathrm{HCl}^{28-31}$ have been used to improve the lead hydride generation efficiency. Flow injection hydride generation methodology has also been successfully utilized for the determination of lead in various samples, such as air filters, ${ }^{24}$ water samples, ${ }^{27}$ calcium supplements, ${ }^{29}$ clinical samples, ${ }^{30,31}$ and wine ${ }^{31}$ by FAAS.

Atom trapping approaches that involve the collection and in situ preconcentration of analyte using a slotted silica and quartz tube were first demonstrated by Watling ${ }^{32}$ and Lau et al., ${ }^{33}$ and since then have attracted considerable interest to achieve lower detection limits by FAAS. ${ }^{34-36}$ The improvement in sensitivity was about 3- to 5-fold for a number of volatile elements, including $\mathrm{Pb}, \mathrm{Cd}, \mathrm{Bi}, \mathrm{Co}, \mathrm{Mn}, \mathrm{Ag}, \mathrm{As}, \mathrm{Sb}$, $\mathrm{Cu}$ and $\mathrm{Se}$, when the mist of sample solution was continuously introduced to a slotted quartz tube atom trap. ${ }^{32}$ Trapping the analyte vapor over a period of time by condensation on the exterior walls of a water-cooled silica tube afforded better sensitivity by factor of 10-50. A different approach for atom trapping was reported by Huang et al. ${ }^{37}$ with a slotted-quartz tube under highly oxidizing flame conditions followed by atomization by changing the fuel-to-oxidant ratio of the flame. In a comparative study of a bare slotted silica tube trap and a water-cooled silica trap in slotted silica tube, better sensitivity was achieved with the former in the determination of $\mathrm{Cd}$ and $\mathrm{Pb}$ from water samples. ${ }^{38}$ Trapped species were atomized either by rapidly increasing the fuel flow rate or by aspirating an organic solvent to the flame. ${ }^{38,39}$

Initial studies of the atom trapping approach for the determination of hydride forming elements by atomic spectrometry involved in situ trapping in graphite furnaces. ${ }^{40}$ Successful studies interfacing hydride generation to silica or quartz tube atom traps have been reported only recently. ${ }^{41-50}$ Korkmaz et al. $^{41}$ used an electrically heated silica trap 
attached to the T-arm of a silica tube atomizer to collect $\mathrm{PbH}_{4}$. Trapped species were released and swept into the flame-heated silica atomizer by raising the temperature of the trap rapidly; a detection limit of $19 \mathrm{ng} \mathrm{L}^{-1}$ was achieved for 60-s trapping (6 mL sample). Similarly, stibine $\left(\mathrm{SbH}_{3}\right)$ was trapped in an electrically-heated quartz tube trap; ${ }^{42,43}$ detection limits achieved for chemical ${ }^{42}$ and electrochemical ${ }^{43}$ generation of stibine were $3.9 \mathrm{ng} \mathrm{L}^{-1}$ and $53 \mathrm{ng} \mathrm{L}^{-1}$, respectively. Introduction of oxygen upstream to an externally heated quartz atomizer during trapping was found to increase the trapping efficiency of stibine ${ }^{44}$ and bismuthine, ${ }^{45}$ but not those of arsine, selenium hydride and tellurium hydride. Using the same approach, arsine and selenium hydride were trapped through the inlet arm of the quartz tube, which was modified to accommodate oxygen delivery to combust hydrogen during trapping. ${ }^{46}$ Very recently, Matusiewicz and Krawczyk collected hydrides of As and Se by using an integrated atom trap (IAT) assembly consisting of a water-cooled single silica tube and a double-slotted quartz tube. ${ }^{47}$ Shortly after this report, the group extended the application of IAT approach to the determination of $\mathrm{Cd}$ and $\mathrm{Pb},{ }^{48}$ tellurium (Te), ${ }^{49}$ and indium (In) and thallium $(\mathrm{Tl})^{50}$ by hydride generation FAAS.

In this paper we described a conceptually similar approach of trapping lead hydride using a quartz tube atomizer for the determination of $\mathrm{Pb}$ by FAAS. Lead hydride was generated on-line by reaction of $\mathrm{Pb}$ in $0.3 \% \quad \mathrm{v} / \mathrm{v} \mathrm{HCl}-3 \% \mathrm{~m} / \mathrm{v}$ $\mathrm{K}_{3} \mathrm{Fe}(\mathrm{CN})_{6}$ medium with $0.2 \% \mathrm{~m} / \mathrm{v} \mathrm{NaBH}$. The gaseous hydride was trapped under fuel-lean flame conditions on the interior walls of a slotted T-tube placed on an air-acetylene flame. Atomization was performed by introducing $50 \mu \mathrm{L}$ of methyl isobutyl ketone (MIBK) through the nebulizer. The detection limit for a sample volume of $7.8 \mathrm{~mL}$ was $28 \mathrm{ng} \mathrm{L}^{-1}$. The accuracy of the method for determination of $\mathrm{Pb}$ from environmental samples was demonstrated by analysis of soil and plant certified reference materials.

\section{Experimental}

\section{Apparatus}

All measurements were performed by use of a PerkinElmer Model 1100B atomic absorption spectrometer equipped with a 10-cm air-acetylene burner. A PerkinElmer $\mathrm{Pb}$ hollow cathode lamp (0.7 mA, $283.3 \mathrm{~nm}$ line) was used. The spectral bandpass was $0.7 \mathrm{~nm}$. Deuterium lamp background correction was used throughout. Data were recorded using an Epson Model LQ850 printer. The schematic diagrams of the flow injection manifold and the slotted quartz T-tube are shown in Figs. 1 and 2, respectively. Two peristaltic pumps (IsmaTec sa MSREGLO) were used with Tygon pump tubes $(1.5 \mathrm{~mm}$ id) delivering $5.2 \mathrm{~mL} \mathrm{~min}^{-1}$. Connection tubings on the sample and reagent lines were made of $0.8 \mathrm{~mm}$ id PTFE. The mixing coil and the transfer line between the gas-liquid separator and the quartz T-tube were, respectively, 10- and 15-cm long PTFE (2 $\mathrm{mm}$ id). The tubing connecting argon supply to the gasliquid separator was also $2 \mathrm{~mm}$ id PTFE. The slotted quartz T-tube was $16 \mathrm{~cm}$ long $(1.4 \mathrm{~cm}$ id). It had two slots: $11 \mathrm{~cm}$ long (lower) and $5 \mathrm{~cm}$ long (upper) at $180^{\circ}$ with respect to each

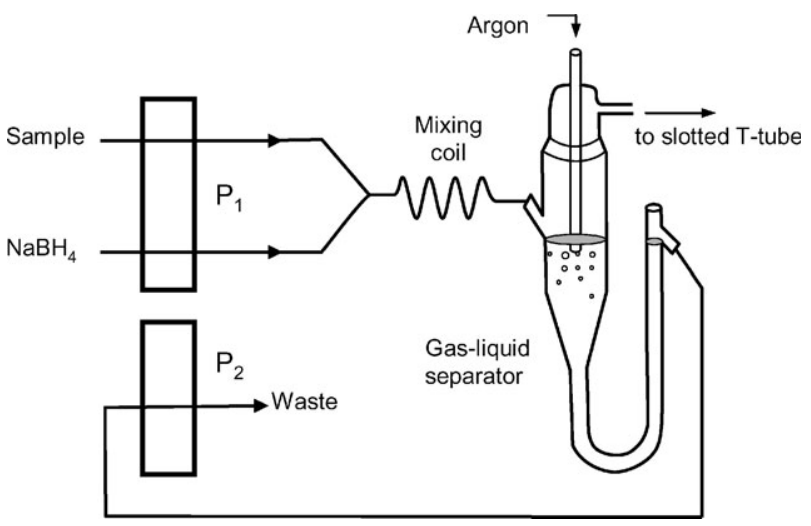

Fig. 1 Schematic diagram of the flow injection hydride generation manifold.

other. The tube was held on the burner head by using the mount for the flame heated quartz tube.

\section{Reagents and solutions}

Deionized water was used in the preparation of all solutions. A $10 \mu \mathrm{g} \mathrm{mL}^{-1} \mathrm{~Pb}$ standard solution was prepared from a $1000 \mu \mathrm{g}$ $\mathrm{mL}^{-1} \mathrm{~Pb}$ standard solution (Aldrich). All standard solutions were prepared by one-stage dilution of the $10 \mu \mathrm{g} \mathrm{mL}^{-1} \mathrm{~Pb}$ solution. Acidity was adjusted with $\mathrm{HCl}$ (Fisher Scientific). Solid $\mathrm{K}_{3} \mathrm{Fe}(\mathrm{CN})_{6}$ (EM Science) was used as the oxidant. Sodium borohydride $\left(\mathrm{NaBH}_{4}\right)$ solution was prepared daily by dissolving the necessary amount of $\mathrm{NaBH}_{4}$ (Alfa) in $0.05 \%$ $\mathrm{m} / \mathrm{v}$ sodium hydroxide (Fisher Scientific). Methyl isobutyl ketone (MIBK, Fisher Scientific) was used for atomization of the trapped species.

\section{Procedure}

A standard or sample solution prepared in $3 \% \mathrm{~m} / \mathrm{v}$ $\mathrm{K}_{3} \mathrm{Fe}(\mathrm{CN})_{6}$ and $0.3 \% \mathrm{v} / \mathrm{v} \mathrm{HCl}$ was continuously pumped at $5.2 \mathrm{~mL} \mathrm{~min}^{-1}$ and mixed on-line with $0.2 \% \mathrm{~m} / \mathrm{v} \mathrm{NaBH}$ solution also running at $5.2 \mathrm{~mL} \mathrm{~min}^{-1}$ (Fig. 1). The volatile lead hydride generated along the mixing coil was separated within the gas-liquid separator and swept into the slotted T-tube. During the trapping of $\mathrm{PbH}_{4}$ for a certain period of time, acetylene and air flow rates were set to $0.9 \mathrm{~L} \mathrm{~min}^{-1}$ and 8.6 $\mathrm{L} \mathrm{min}^{-1}$, respectively, to produce an extremely oxidizing flame. Atomization of the trapped $\mathrm{Pb}$ species was achieved by aspirating $50 \mu \mathrm{L}$ of methyl isobutyl ketone (MIBK) through the nebulizer. The solvent was delivered either by a micropipette or via a six-port flow injection valve. The rapid change in

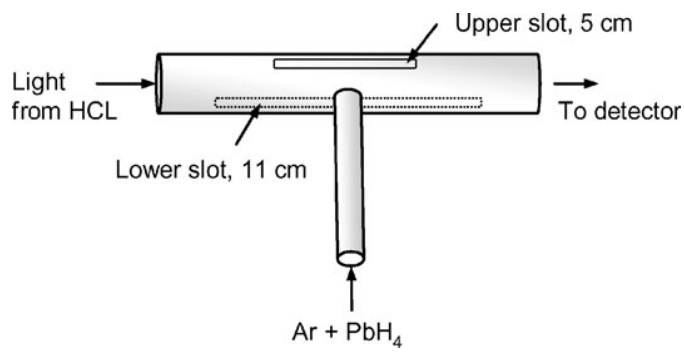

Fig. 2 Schematic diagram of the slotted T-tube. 
the flame characteristics from oxidizing (fuel-lean) to reducing (fuel-rich) flame resulted in a sharp transient signal

\section{Method development}

The experimental variables for the generation of $\mathrm{PbH}_{4}$, trapping and atomization were optimized by a univariate method to obtain the greatest peak height absorbance. Five replicate measurements were made with either 1.0 or $2.0 \mu \mathrm{g} \mathrm{L}^{-1} \mathrm{~Pb}$ standard solution. The acidity of the solution containing $4 \%$ $\mathrm{m} / \mathrm{v} \mathrm{K}_{3} \mathrm{Fe}(\mathrm{CN})_{6}$ was varied from 0.1 to $0.8 \% \mathrm{v} / \mathrm{v} \mathrm{HCl}$ while other parameters were kept constant. The concentration of $\mathrm{K}_{3} \mathrm{Fe}(\mathrm{CN})_{6}$ was increased from 0.5 to $4 \% \mathrm{~m} / \mathrm{v}$ to affect the hydride generation efficiency for a series of standard solutions acidified to $0.3 \mathrm{v} / \mathrm{v} \mathrm{HCl}$. The length of the mixing coil was varied from 10 to $30 \mathrm{~cm}$. For the transfer line, a $15 \mathrm{~cm}$ long ( $2 \mathrm{~mm}$ id) tube was used to minimize the distance between the gas-liquid separator and the slotted T-tube. The effect of $\mathrm{NaBH}_{4}$ concentration was investigated between 0.05 and $2.0 \% \mathrm{~m} / \mathrm{v}$ for a $1.0 \mu \mathrm{g} \mathrm{L}^{-1} \mathrm{~Pb}$ standard solution containing $0.3 \% \mathrm{v} / \mathrm{v} \mathrm{HCl}$ and $3 \% \mathrm{~m} / \mathrm{v} \mathrm{K}_{3} \mathrm{Fe}(\mathrm{CN})_{6}$.

Argon gas was used to strip $\mathrm{PbH}_{4}$ from the gas-liquid separator and pass it to the slotted quartz T-tube. The flow rate of argon was varied from 80 to $600 \mathrm{~mL} \mathrm{~min}^{-1}$. Different flame conditions were studied to achieve maximum trapping efficiency. The flow rate of fuel (acetylene) was adjusted to a minimum value $\left(0.9 \mathrm{~L} \mathrm{~min}^{-1}\right)$ to keep the flame lit and the flow rate of the oxidant (air) was varied from 8.0 to $9.2 \mathrm{~L} \mathrm{~min}^{-1}$. For the atomization of the trapped species, the volume of organic solvent (MIBK) aspirated to the flame was varied from 15 to $100 \mu \mathrm{L}$.

\section{Method validation}

Two NIST standard reference materials were used for method validation: SRM 2709 (San Joaquin Soil) and SRM 1515 (Apple Leaves). Approximately $0.1 \mathrm{~g}$ for the soil and $0.3 \mathrm{~g}$ for the apple leaves were weighed into PTFE beakers and digested in a mixture of $3.0 \mathrm{~mL}$ of concentrated $\mathrm{HNO}_{3}$ (Fisher Scientific) and $1 \mathrm{~mL}$ of concentrated HF (EM Science) on a hot plate. ${ }^{19}$ After complete dissolution, the contents were heated to dryness to evaporate the acids. The residue was then dissolved and diluted to $25 \mathrm{~mL}$ with $0.3 \% \mathrm{v} / \mathrm{v} \mathrm{HCl}$. For the determination of $\mathrm{Pb}$ by HG-FAAS, subsequent dilutions were performed with $0.3 \% \mathrm{v} / \mathrm{v} \mathrm{HCl}$ solutions so that the concentration of $\mathrm{Pb}$ in the analysis solutions was between 0.4 and $0.8 \mu \mathrm{g} \mathrm{L}^{-1}$. Solid $\mathrm{K}_{3} \mathrm{Fe}(\mathrm{CN})_{6}(3 \% \mathrm{~m} / \mathrm{v})$ was added to each sample solution and the solutions were analyzed for $\mathrm{Pb}$ with the optimized system. External calibration was used for quantification with standard solutions ranging from 0 to $2.0 \mu \mathrm{g} \mathrm{L}^{-1}$ in $0.3 \% \mathrm{v} / \mathrm{v} \mathrm{HCl}$. Standard solutions also contained $3 \% \mathrm{~m} / \mathrm{v} \mathrm{K}_{3} \mathrm{Fe}(\mathrm{CN})_{6}$.

\section{Results and discussion}

\section{Optimum conditions for generation of $\mathrm{PbH}_{4}$}

The improvement in the generation of lead hydride in an acid-oxidant medium is attributed to the efficient oxidation of $\mathrm{Pb}^{2+}$ to metastable $\mathrm{Pb}^{4+}$, from which $\mathrm{PbH}_{4}$ is generated. $^{20-31,51-53}$ Further, depending on the oxidant, the type of acid used to acidify samples is critical to achieve desired sensitivity and precision. ${ }^{22}$ Both nitric and lactic acids improved efficiency in the presence of $\left(\mathrm{NH}_{4}\right)_{2} \mathrm{~S}_{2} \mathrm{O}_{8}, \mathrm{~K}_{2} \mathrm{Cr}_{2} \mathrm{O}_{7}$ or $\mathrm{H}_{2} \mathrm{O}_{2}$ as oxidants, but the best sensitivity was achieved with lactic acid- $\mathrm{K}_{2} \mathrm{Cr}_{2} \mathrm{O}_{7}$ medium. ${ }^{26}$ Oxalic acid was used with $\mathrm{Ce}\left(\mathrm{NO}_{3}\right)_{4},{ }^{51}$ while tartaric acid was preferred in the presence of $\left(\mathrm{NH}_{4}\right)_{2} \mathrm{~S}_{2} \mathrm{O}_{8} \cdot{ }^{52}$ Similarly, tartaric acid $/ \mathrm{Na}_{2} \mathrm{~S}_{2} \mathrm{O}_{8}$ was used, although $\mathrm{HNO}_{3}-\mathrm{Na}_{2} \mathrm{~S}_{2} \mathrm{O}_{8}$ did afford equal sensitivity. ${ }^{53}$ Precision was poor when $\mathrm{HCl}$ was used with $\mathrm{Na}_{2} \mathrm{~S}_{2} \mathrm{O}_{8} \cdot{ }^{53}$ Conversely, $\mathrm{HCl}$ was the most suitable acid with $\mathrm{K}_{3} \mathrm{Fe}(\mathrm{CN})_{6}$, a relatively mild oxidant. ${ }^{28-31}$

In this study, $\mathrm{HCl}-\mathrm{K}_{3} \mathrm{Fe}(\mathrm{CN})_{6}$ acid-oxidant medium was used as it has been frequently reported to provide by far the highest sensitivity in the generation of lead hydride. The effect of $\mathrm{HCl}$ concentration on the peak height absorbance is illustrated in Fig. 3. The maximum signal was obtained within a narrow region between 0.25 and $0.4 \% \mathrm{v} / \mathrm{v} \mathrm{HCl}$, for which $0.3 \% \mathrm{v} / \mathrm{v}$ was chosen as the optimum value. The absorbance from $2 \mu \mathrm{g} \mathrm{L}^{-1} \mathrm{~Pb}$ in $0.3 \mathrm{v} / \mathrm{v} \mathrm{HCl}$ increased rapidly with an increase in the concentration of $\mathrm{K}_{3} \mathrm{Fe}(\mathrm{CN})_{6}$ from 0.5 to 1.0 $\mathrm{m} / \mathrm{v}$ that peaked at $1.5 \% \mathrm{~m} / \mathrm{v} \mathrm{K}_{3} \mathrm{Fe}(\mathrm{CN})_{6}$ (Fig. 4a). A gradual increase in the signal with higher concentrations of $\mathrm{K}_{3} \mathrm{Fe}(\mathrm{CN})_{6}$ was apparently from a $\mathrm{Pb}$ impurity in the $\mathrm{K}_{3} \mathrm{Fe}(\mathrm{CN})_{6}$ solution, as displayed by the signal profile of the blank (Fig. 4b). However, the precision among the daily absorbances from freshly prepared $\mathrm{Pb}$ solutions $\left(2 \mu \mathrm{g} \mathrm{L}^{-1}\right)$ was poor with $1.5 \%$ $\mathrm{m} / \mathrm{v} \mathrm{K}_{3} \mathrm{Fe}(\mathrm{CN})_{6}$, which necessitated the use of $3 \% \mathrm{~m} / \mathrm{v}$ $\mathrm{K}_{3} \mathrm{Fe}(\mathrm{CN})_{6}$ to maintain the stability in the daily signals. For $\mathrm{NaBH}_{4}$, a relatively low concentration $(0.2 \% \mathrm{~m} / \mathrm{v})$ was adequate to successfully generate $\mathrm{PbH}_{4}$ (Fig. 5). No significant increase in the signals occurred for higher concentrations of $\mathrm{NaBH}_{4}$.

In the last stage of the hydride generation, the length of mixing coil and the flow rates of the solutions were optimized with $1 \mu \mathrm{g} \mathrm{L}^{-1} \mathrm{~Pb}$ solution. Increasing the length of the mixing coil from 10 to $30 \mathrm{~cm}$ had almost no effect on the absorbance signals, suggesting that $\mathrm{PbH}_{4}$ was successfully generated along a $10-\mathrm{cm}$ long tubing. The flow rates for sample and $\mathrm{NaBH}_{4}$ solutions were $5.2 \mathrm{~mL} \mathrm{~min}^{-1}$ during the optimization studies

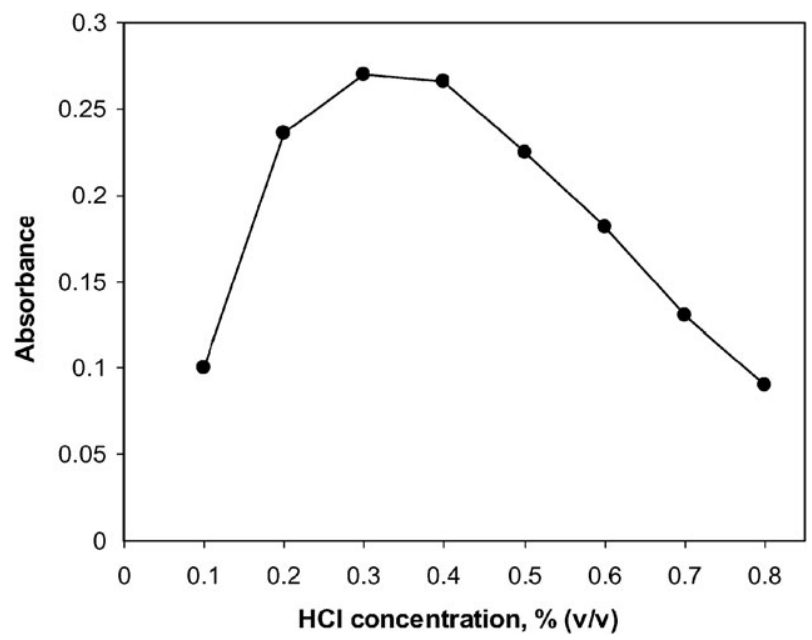

Fig. 3 Effect of $\mathrm{HCl}$ concentration on peak height absorbance for a solution containing $2 \mu \mathrm{g} \mathrm{L}^{-1} \mathrm{~Pb}$ and $4 \% \mathrm{~m} / \mathrm{v} \mathrm{K}_{3} \mathrm{Fe}(\mathrm{CN})_{6}$. 


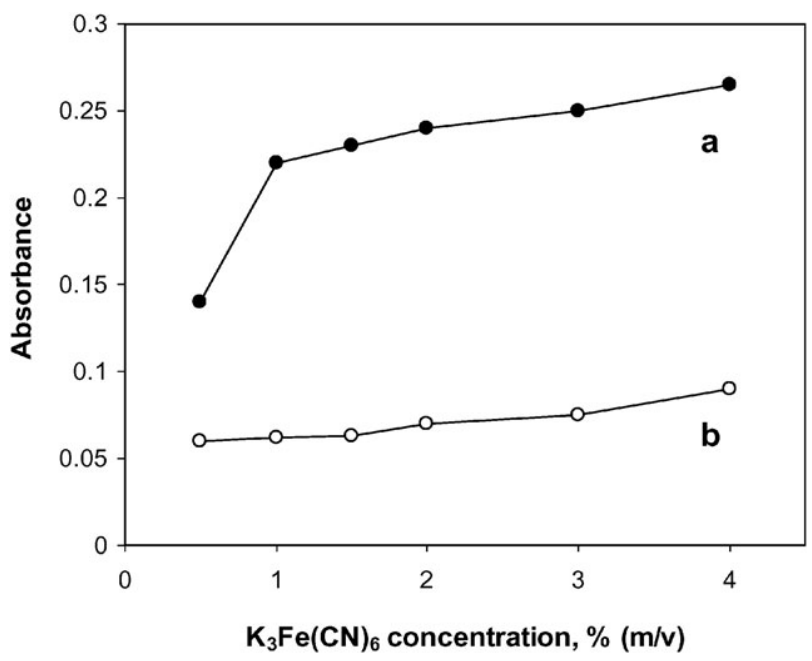

Fig. 4 Effect of $\mathrm{K}_{3} \mathrm{Fe}(\mathrm{CN})_{6}$ concentration on (a) peak height absorbance, (b) blank + background absorption, for a $2 \mu \mathrm{g} \mathrm{L}^{-1} \mathrm{~Pb}$ solution in $0.3 \% \mathrm{v} / \mathrm{v} \mathrm{HCl}$.

described above. Final examination indicated that these were the optimum settings in terms of sensitivity versus sample consumption. Increasing the flow rates improved the sensitivity to some extent, but not proportionately to the volume of sample used: most of the sample was wasted without a significant gain in sensitivity.

\section{Trapping and atomization conditions}

In continuous mode hydride generation, the atom number density and the residence time of the atoms in the light path are mainly determined by the speed with which the particular hydride is transported to the atomizer cell, which consequently influences the peak shape and peak height sensitivity. In atom trapping hydride generation, however, the peak height sensitivity is dependent on both trapping and atomization efficiency. It was proposed that analytes accumulate either as metals or oxides on the surface of silica or quartz traps, ${ }^{38,39,54}$ suggesting that direct contact of volatile hydride with the surface of the atom trap cell is essential for a certain period

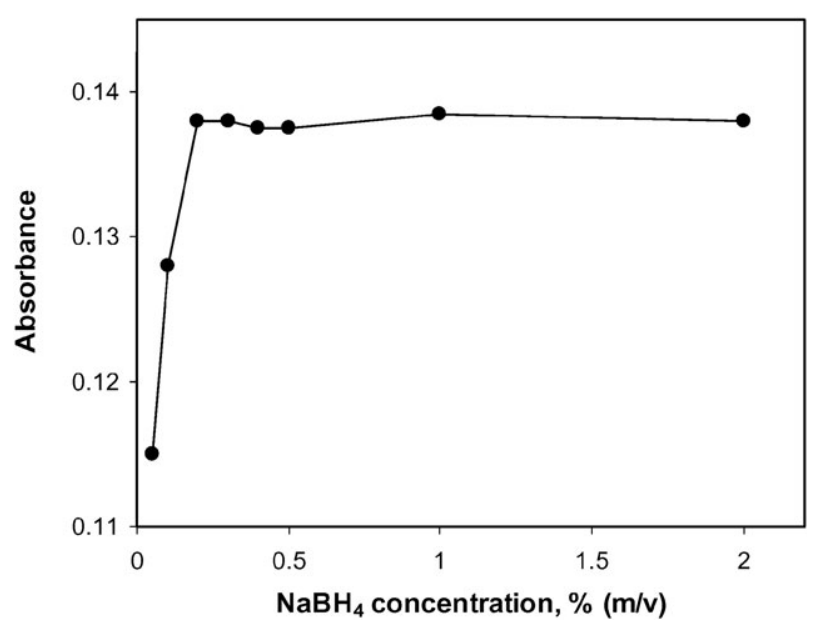

Fig. 5 Effect of $\mathrm{NaBH}_{4}$ concentration on peak height absorbance. Lead solution $\left(1 \mu \mathrm{g} \mathrm{L}^{-1}\right)$ is in $0.3 \% \mathrm{v} / \mathrm{v} \mathrm{HCl}-3 \% \mathrm{~m} / \mathrm{v} \mathrm{K}_{3} \mathrm{Fe}(\mathrm{CN})_{6}$. of time to achieve efficient collection. While the argon flow rate determines the duration of the contact, the flame conditions (e.g., temperature and composition) impact on the stability of trapped species. Thus, prior to examining the effect of argon flow rate, the flame composition of the acetylene-air flame was optimized on the trapping efficiency of plumbane. The optimum settings for the flame gases were $0.9 \mathrm{~L} \mathrm{~min}^{-1}$ for acetylene (fuel) and $8.6 \mathrm{~L} \mathrm{~min}^{-1}$ for air (oxidant), which ensured a highly fuel-lean (oxidizing) flame during trapping. The acetylene flow rate was the lowest value to maintain the flame burning. Further increase in the air flow rate resulted in a noisy and unstable flame that went out shortly after it was lit. Stable flame conditions were also obtained for $1.0 \mathrm{~L} \mathrm{~min}^{-1}$ acetylene and $9.2 \mathrm{~L} \mathrm{~min}^{-1}$ air flow rates, but these conditions did not provide any significant improvement in trapping efficiency.

The optimum flow rate of argon carrier gas ranged between 200 and $320 \mathrm{~mL} \mathrm{~min}^{-1}$ : this ensured efficient trapping of $\mathrm{Pb}$ species. The flow rate was adjusted to $250 \mathrm{~mL} \mathrm{~min}^{-1}$ thereafter. At lower argon flow rates (e.g., 100-120 mL min ${ }^{-1}$ ), signals were significantly low, which was most likely due to the loss of $\mathrm{PbH}_{4}$ before reaching the slotted T-tube trap. The signals gradually decreased with increasing argon flow rate above $320 \mathrm{~mL} \min ^{-1}$ since the volatile plumbane was swept rapidly without sufficient physical contact with the slotted T-tube.

Atomization was performed by nebulizing methyl isobutyl ketone (MIBK) to the fuel-lean flame. A volume of $50 \mu \mathrm{L}$ of MIBK was sufficient to produce a hot, fuel-rich flame, allowing rapid release and atomization of the trapped species from the walls of the slotted tube. Greater volumes up to $100 \mu \mathrm{L}$ did not show any enhancement in the signals, but rather increased the background absorption up to 0.07 for 30 -s trapping. Alternatively, atomization was performed by manually switching the air and acetylene flow rates to the stoichiometric flame settings. Though this procedure eliminated the background absorption significantly, it was not practical because of the speed and operator skill required to maintain the precision between replicate atomizations.

\section{Analytical figures of merit}

Calibration was performed with a number of $\mathrm{Pb}$ standard solutions ranging from 0 to $2.0 \mu \mathrm{g} \mathrm{L}^{-1} \mathrm{~Pb}$. The relative standard deviation (RSD) ranged between 2 and $4 \%$ for 30 -s trapping. The detection limits and characteristic concentrations were measured for a period of 30,60 and $90 \mathrm{~s}$ trapping using a sample volume of $2.6,5.2$ and $7.8 \mathrm{~mL}$, respectively. The results are given in Table 1. A comparison of analytical performances is also provided in Table 2. The HG-AT procedure afforded significant improvements in the detection limits with respect to those reported for ETAAS and HG-FAAS.

Table 1 Effect of trapping time on detection limit $(3 s, n=13)$ and characteristic concentration

\begin{tabular}{llll}
\hline $\begin{array}{l}\text { Trapping } \\
\text { period } / \mathrm{s}\end{array}$ & $\begin{array}{l}\text { Sample } \\
\text { volume } / \mathrm{mL}\end{array}$ & $\begin{array}{l}\text { Characteristic } \\
\text { concentration } / \mu \mathrm{g} \mathrm{L}^{-1}\end{array}$ & $\begin{array}{l}\text { Detection } \\
\text { limit } / \mu \mathrm{g} \mathrm{L}^{-1}\end{array}$ \\
\hline 30 & 2.6 & 0.049 & 0.075 \\
60 & 5.2 & 0.025 & 0.047 \\
90 & 7.8 & 0.019 & 0.028 \\
\hline
\end{tabular}


Table 2 Comparison of detection limits for the determination of $\mathrm{Pb}$ by different atomic spectrometry techniques. The values are based on the peak area absorbance for ETAAS and peak height absorbance for FAAS

\begin{tabular}{llll}
\hline Technique & $\begin{array}{l}\text { Sample } \\
\text { volume } / \mathrm{mL}\end{array}$ & $\begin{array}{l}\text { Detection } \\
\text { limit } / \mathrm{g} \mathrm{L}^{-1}\end{array}$ & Reference \\
\hline ETAAS & 0.02 & 0.4 & $\begin{array}{l}\text { PE 4100ZL } \\
\text { catalogue }\end{array}$ \\
HG-AT-ETAAS & 1.0 & 0.03 & 29 \\
HG-FAAS & 0.5 & 0.7 & 30 \\
HG-AT-FAAS & 6.0 & 0.019 & 41 \\
HG-IAT-FAAS & 2.0 & 0.40 & 48 \\
HG-AT-FAAS & 7.8 & 0.028 & This study \\
\hline
\end{tabular}

Detection limits were similar to those reported for HG-ATETAAS $^{29}$ and HG-AT-FAAS ${ }^{41}$ and were significantly lower than that for HG-IAT-FAAS. ${ }^{48}$

The relationship between detection limit and sample volume (Table 1) was consistent with the equation " $C_{\mathrm{L}}=b / V+a$ " proposed by Tyson ${ }^{55}$ for flow-based systems, where " $C_{\mathrm{L}}$ " is the detection limit, " $V$ " is the sample volume, and " $a$ " and " $b$ " are constants. The data fit a detection limit equation of $C_{\mathrm{L}}=0.174( \pm 0.023) / V+0.009( \pm 0.004)$ with a correlation coefficient $\left(r^{2}\right)$ of 0.985 . The values in the parenthesis are uncertainties for coefficients " $b$ " and " $a$ ", respectively. A plot of the detection limit versus sample volume is therefore consistent with a rectangular hyperbola (Fig. 6), suggesting that the improvement in the detection limit would be slight for sample volumes greater than $6 \mathrm{~mL}$ due to the impurities in the reagents; the lowest detection limit would be $C_{\mathrm{L}}=0.009 \mu \mathrm{g}$ $\mathrm{L}^{-1}$ as $V=\infty$. In this study, the major source of blank contamination was from the impurities in $\mathrm{K}_{3} \mathrm{Fe}(\mathrm{CN})_{6}$. Blank absorbance was about 0.07 for 30 -s trapping ( $2.6 \mathrm{~mL}$ sample); therefore, it was concluded that better detection limits could be achieved by using high purity potassium ferricyanide.

\section{Application to analysis of samples for $\mathbf{P b}$}

The accuracy of procedure was validated by analysis of two NIST standard reference materials, SRM 2709 (San Joaquin Soil) and SRM 1515 (Apple Leaves). The results for $\mathrm{Pb}$ are summarized in Table 3. No significant differences were found at the $95 \%$ confidence level $(p=0.05)$ between experimental and certificate values since the confidence interval of the experimental values included the mean of the certificate values. A number of transition elements, including $\mathrm{Co}, \mathrm{Cu}, \mathrm{Mn}, \mathrm{Ni}$ and $\mathrm{V}$, were reported to increase the lead signal by about $20-60 \%$ when plumbane was generated in $\mathrm{H}_{2} \mathrm{O}_{2}-\mathrm{HNO}_{3}$ medium. ${ }^{3}$ The interference from $\mathrm{Fe}$ was even more complicated: the $\mathrm{Pb}$ signal increased in $\mathrm{H}_{2} \mathrm{O}_{2}-\mathrm{HNO}_{3}$ medium at a $\mathrm{Pb}: \mathrm{Fe}$ ratio of 1:0.016, but was suppressed at a $\mathrm{Pb}: \mathrm{Fe}$ ratio of 1:1

Table 3 Results obtained from certified reference materials by HGAT-FAAS. Results are given as mean $\pm 95 \%$ confidence interval of 4 replicates. Certified values are given as mean $\pm 95 \%$ confidence interval

\begin{tabular}{llc}
\hline & $\begin{array}{l}\text { San Joaquin } \\
\text { Soil SRM 2709 }\end{array}$ & $\begin{array}{c}\text { Apple Leaves } \\
\text { SRM 1515 }\end{array}$ \\
\hline Found $/ \mu \mathrm{g} \mathrm{g}^{-1}$ & $18.6 \pm 1.3$ & $0.49 \pm 0.04$ \\
Certified $/ \mu \mathrm{g} \mathrm{g}^{-1}$ & $18.9 \pm 0.5$ & $0.47 \pm 0.024$ \\
Accuracy $(\%)$ & $98.2 \pm 6.1$ & $105.2 \pm 4.9$ \\
\hline
\end{tabular}

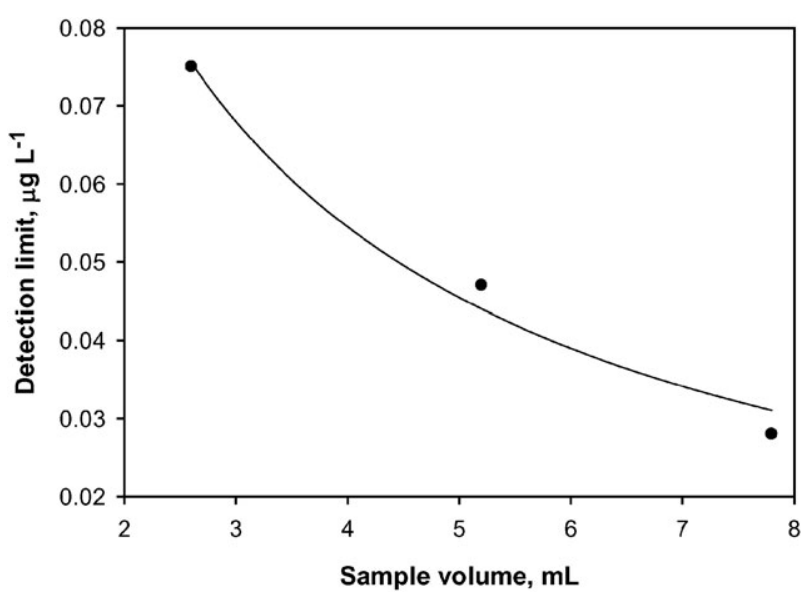

Fig. 6 The effect of sample volume on the detection limit for $\mathrm{Pb}$ by HG-AT-FAAS. Blank solution $(n=13)$ contained $0.3 \% \mathrm{v} / \mathrm{v} \mathrm{HCl}$ and $3 \% \mathrm{~m} / \mathrm{v} \mathrm{K}_{3} \mathrm{Fe}(\mathrm{CN})_{6}$.

when $\mathrm{S}_{2} \mathrm{O}_{8}{ }^{2-}$ was the oxidant. ${ }^{3}$ In this study, the soil SRM contained considerably higher levels of these interfering elements: $\mathrm{Cu}\left(34.6 \mu \mathrm{g} \mathrm{g}^{-1}\right), \mathrm{Fe}(3.50 \%), \mathrm{Mn}\left(538 \mu \mathrm{g} \mathrm{g}^{-1}\right)$, $\mathrm{Ni}\left(88 \mu \mathrm{g} \mathrm{g}^{-1}\right), \mathrm{V}\left(112 \mu \mathrm{g} \mathrm{g}^{-1}\right)$. The lowest value was for $\mathrm{Cu}$ for which $\mathrm{Pb}$-to- $\mathrm{Cu}$ ratio was about 1:2 in the analysis solutions; nevertheless, the procedure was highly robust against the concomitant ions in the soil matrix. No significant enhancement or suppression was observed in $\mathrm{Pb}$ signals. The acidity of the samples was, however, a critical point that deserved careful adjustment to achieve high precision and accuracy. In the preparation of the samples by $\mathrm{HNO}_{3}-\mathrm{HF}$ digestion, the contents were heated to dryness after dissolution to completely remove excess acids and then diluted to the appropriate volume with $0.3 \% \mathrm{v} / \mathrm{v} \mathrm{HCl}$.

\section{Conclusion}

The hydride generation atom trapping approach has been proven to be highly suitable to achieve better sensitivity for accurate determination of hydride forming elements at trace levels since the traps made up of quartz or silica tubes act, in a sense, like an enrichment device. ${ }^{41-50}$ In this study, we have demonstrated in situ trapping of lead hydride species on the inner walls of a flame-heated quartz tube under highly oxidizing flame conditions followed by the release of trapped species by introducing MIBK. The method is simple, cost-effective and yet offers the capability for the determination of lead at trace levels by FAAS. The acidity of the sample solution and the concentration of the oxidant, $\mathrm{K}_{3} \mathrm{Fe}(\mathrm{CN})_{6}$, require close control to maintain precision and accuracy. While the former is influential in the efficacy of the generation of plumbane, the latter mostly impacts on the detection limits as it increases the blank signals notably due to the impurities of $\mathrm{Pb}$. Thus, it is expected that detection limits could be further improved with the use of high purity potassium ferricyanide.

\section{Acknowledgements}

The authors gratefully acknowledge the Scientific and Technical Research Council of Turkey for financial support for 
Nusret Ertaș during the course of this study. This paper is funded in part by a grant from the National Oceanic and Atmospheric Administration (NOAA). The views expressed herein are those of the authors and do not necessarily reflect the views of NOAA or any of its sub-agencies.

\section{References}

1 S. J. Hill, J. B. Dawson, W. J. Price, I. L. Shuttler, C. M. M. Smith and J. F. Tyson, J. Anal. At. Spectrom., 1998, 13,131R.

2 A. Taylor, S. Branch, D. Halls, M. Patriarca and M. White, $J$. Anal. At. Spectrom., 2002, 17, 414.

3 M. R. Cave, O. Butler, S. R. N. Chenery, J. M. Cook, M. S. Cresser and D. L. Miles, J. Anal. At. Spectrom., 2001, 16, 194.

4 Z. Fang, Flow Injection Atomic Absorption Spectrometry, Wiley, New York, 1995.

5 J. F. Tyson, Anal. Chim. Acta, 1990, 234, 3

6 Z. Fang, M. Sperling and B. Welz, J. Anal. At. Spectrom., 1991, 6, 301 .

7 D. Rodriguez, P. Fernandez, C. Perez-Conde, A. Gutierrez and C. Camara, Fresenius' J. Anal. Chem., 1994, 349, 442.

8 R. L. Ma, V. Van Mol and F. Adams, Anal. Chim. Acta, 1994, 285, 33

9 F. M. Fernandez, J. D. Stripeikis, M. B. Tudino and O. T. Troccoli, Analyst, 1997, 122, 679.

10 E. Bulska, M. Walcerz, W. Jedral and A. Hulanicki, Anal. Chim. Acta $1997,357,133$

11 H. Lancester, G. D. Marshall, E. L. Gazola, J. Ruzicka and G. D. Christian, Analyst, 1994, 119, 1459.

12 J. Ruzicka and A. Arndal, Anal. Chim. Acta, 1989, 216, 243.

13 Z. Fang, M. Sperling and B. Welz, J. Anal. At. Spectrom., 1990, 5, 639.

14 M. Sperling, X. Yin and B. Welz, J. Anal. At. Spectrom., 1991, 6, 295.

15 R. Lima, K. C. Leandro and R. E. Santelli, Talanta, 1996, 43, 977.

16 R. E. Santelli, M. Gallego and M. Valcarcel, Talanta, 1994, 41, 817.

17 Y. A. Zhang, P. Riby, A. G. Cox, C. W. McLeod, A. R. Date and Y. Y. Cheung, Analyst, 1988, 113, 125.

18 A. M. Naghmush, K. Pyrzynska and M. Trojanowicz, Talanta, 1995, 42, 851

19 L. Elçi, Z. Arslan and J. F. Tyson, Spectrochim. Acta, Part B, 2000, $\mathbf{5 5}, 1109$.

20 J. Dedina and D. L. Tsalev, Hydride Generation Atomic Absorption Spectrometry, Wiley, New York, 1995.

21 X.-P. Yan and Z.-M. Ni, Anal. Chim. Acta, 1994, 291, 89.

22 C. Camara and Y. Madrid, Analyst, 1994, 119, 1647.

23 K. Jin and M. Taga, Anal. Chim. Acta, 1982, 143, 229.
24 H. M. F. Tavares, M. T. S. D. Vasconcelos, A. A. S. C. Machado and P. A. P. Silva, Analyst, 1993, 118, 1433.

25 C. M. Mena, C. Cabrera, M. L. Lorenzo and M. C. Lopez, J. Agric. Food Chem., 1997, 45, 1812.

26 Y. Madrid, D. Chakraborti and C. Camara, Microchim. Acta, $1995,120,63$.

27 M. Chikuma and H Aoki, J. Anal. At. Spectrom., 1993, 8, 415.

28 R. Thao and H. Zhou, Fenxi Huaxue, 1985, 13, 283.

29 J. F. Tyson, R. I. Ellis, G. Carnrick and F. Fernandez, Talanta, 2000, 52, 403.

30 A. Berkkan and N. Ertaș, Talanta, 2004, 64, 423.

31 W. Chuachuad and J. F. Tyson, J. Anal. At. Spectrom., 2005, 20, 282.

32 R. J. Watling, Anal. Chim. Acta, 1977, 94, 181.

33 C. Lau, A. Held and R. Stephens, Can. J. Spectrosc., 1976, 21, 100.

34 C. M. Lau, A. M. Ure and T. S. West, Anal. Chim. Acta, 1982, 141, 213.

35 C. M. Lau, A. M. Ure and T. S. West, Anal. Chim. Acta, 1983, 146, 171.

36 H. Matusiewicz, Spectrochim. Acta, Part B, 1997, 52, 1711.

37 G. Huang, S. Qian and H. Yang, Fenxi Huaxue, 1995, 41, 707.

38 N. Ertaş, D. K. Korkmaz, S. Kumser and O. Y. Ataman, J. Anal. At. Spectrom., 2002, 17, 1415.

39 D. Korkmaz, S. Kumser, N. Ertaș, M. Mahmuta and O. Y. Ataman, J. Anal. At. Spectrom., 2002, 17, 1610.

40 H. Matusiewicz and R. E. Sturgeon, Spectrochim. Acta, Part B, 1996, 51, 377.

41 D. K. Korkmaz, N. Ertaş and O. Y. Ataman, Spectrochim. Acta, Part B, 2002, 57, 571.

42 D. Korkmaz, J. Dědina and O. Y. Ataman, J. Anal. At. Spectrom., 2004, 19, 255

43 İ. Menemenlioglu, D. Korkmaz and O. Y. Ataman, Spectrochim. Acta, Part B, 2007, 62, 40.

44 J. Kratzer and J. Dedina, Spectrochim. Acta, Part B, 2005, 60, 859

45 J. Kratzer and J. Dedina, J. Anal. At. Spectrom., 2006, 21, 208.

46 J. Kratzer and J. Dedina, Anal. Bioanal. Chem., 2007, 388, 793.

47 H. Matusiewicz and M. Krawczyk, Anal. Sci., 2006, 22, 249.

48 H. Matusiewicz and M. Krawczyk, Microchem. J., 2006, 83, 17.

49 H. Matusiewicz and M. Krawczyk, Spectrochim. Acta, Part B, 2007, 62, 309.

50 H. Matusiewicz and M. Krawczyk, J. Braz. Chem. Soc., 2007, 18, 304.

51 J. Li, F. Lu, T. Umemura and K.-I. Tsunoda, Anal. Chim. Acta, 2000, 419, 65.

52 J. F. N. Carrijo, L. C. Brasil and N. M. M. Coelho, J. Braz. Chem. Soc., 2005, 16, 520

53 N. Maleki, A. Safavi and Z. Ramezani, J. Anal. At. Spectrom., $1999, \mathbf{1 4}, 1227$.

54 T. S. West, Anal. Proc., 1988, 25, 240.

55 J. F. Tyson, J. Anal. At. Spectrom., 1999, 14, 169. 